\title{
Prevention of asthma
}

\author{
J.K. Peat
}

Prevention of asthma. J.K. Peat. CERS Journals Ltd 1996.

ABSTRACT: Environmental factors which have changed in the last decade or so appear to be largely responsible for the increase in the prevalence of asthma in affluent countries. It should, therefore, be possible to design interventions to reverse these recent trends and reduce the incidence of asthma. Primary preventive strategies have the potential not only to reduce acquisition of sensitization to common allergens and the risk that symptoms will develop subsequently, but also to reduce morbidity in those who already have persistent disease. There is accumulating epidemiological evidence that a dietary exess of sodium and omega-6 fatty acids, a dietary deficiency of antioxidant vitamins and omega-3 fatty acids, reduced rates of breastfeeding and exposure to allergens and environmental tobacco smoke are all involved in the aetiology of asthma. The modification of these factors has the potential to reduce the incidence and thus the prevalence of this disease. Environmental intervention should be particularly effective in children who have inherited or acquired characteristics which put them at high risk of developing asthma. With the evidence now available, it seems reasonable to assume that interventions which are based on our current knowledge of risk factors could achieve a 50\% reduction in the prevalence of asthma in the next generation of children.

Eur Respir J., 1996; 9, 1545-1555.

\author{
Correspondence: J.K. Peat \\ Dept of Medicine \\ University of Sydney \\ Sydney \\ NSW 2006 \\ Australia \\ Keywords: Allergens \\ asthma \\ diet \\ environment \\ epidemiology \\ risk factors
}

Received: March 141996

Accepted for publication March 251996
Environmental factors which have changed in the last two decades appear to be largely responsible for an increased prevalence of asthma in affluent countries [1-6]. This implies that it is possible to design interventions to reverse these trends and reduce the incidence of asthma. Primary preventive strategies have the potential to reduce rates of acquisition of sensitization to common allergens and the risk that symptoms will subsequently develop and also to reduce morbidity in those who already have persistent disease. This review examines the evidence that there are avoidable factors which, if modified, have the potential to reduce the incidence and, thus, the prevalence of asthma.

\section{Reducing the prevalence of asthma}

Applied epidemiological studies can provide a systematic approach to reducing the prevalence of asthma. As many as $25 \%$ of children in affluent countries now report that they have wheezed in the last year [7-10], although only half this number have an asthmatic illness which has clinical importance. Data from studies which have measured the burden and distribution of asthma and which have quantified the aetiological factors can be used to estimate the fraction of illness that is attributable to modifiable risk factors [11], but different types of studies will be needed in the future to estimate the effectiveness and the economic implications of preventive interventions.

An interventionist approach to preventing asthma is urgently needed because recent advances in managing asthma have led to only small reductions in the overall burden of morbidity in the community. Although improvements in treating and managing asthma have led to decreases in asthma mortality rates in recent years in Australia and New Zealand [12], increases in hospitalizations for childhood asthma were reported up to 1990 [13], and improvements in management skills, in awareness and in the promotion of preventive medications have not been accompanied by an expected decrease in the prevalence of asthma. Recent studies in Australia show that $25 \%$ of 8-11 year old children have used a beta-agonist inhaler in the previous year, and at least $10 \%$ use a preventive medi-cation for asthma [14].

Because it is unlikely that new advances in management practices in the near future will substantially reduce morbidity or cure asthma, it is important that an interventionist approach to control or to modify environmental and dietary factors is considered. This type of approach will depend on the reallocation of health funds to information services, to resources for interventions and to educational strategies. Such interventions will be costeffective in the long-term because asthma management incurs substantial costs once the disease has become a chronic condition [15-17].

\section{Environmental risk factors}

\section{Inhaled allergens.}

The vast majority of asthmatics (approximately 80-90\%) are sensitized to at least one common allergen [18, 19]. 
Different allergens are dominant in different climatic regions but indoor allergens are especially important because many people spend most of their time indoors. Some allergens may be more closely associated with asthma for the following reasons: the particles are smaller and, therefore, more respirable; the allergens are more potent in their enzymic activity; exposure reaches very high levels or is perennial.

Allergen exposure clearly influences the development of an atopic phenotype. It has been suggested that allergen exposure during very early life when the immune system is developing, may produce memory T-cells which manufacture specific immunoglobulin E (IgE) antibodies when re-exposed to allergens in later life [20]. We found that children who become sensitized in early childhood are at a much higher risk of having asthma than those who become sensitized later [21], and that children with high levels of sensitization are most likely to have symptoms which are clinically important and which impact on lifestyle [22]. In a prospective cohort study of infants, SPORIK et al. [23] found that the development of wheeze was related to the level of house-dust mite allergens in the child's bed, and that children who were exposed to high levels were five times more likely to have asthma at the age of $11 \mathrm{yrs}$ [23]. These studies imply that reduction of allergen exposure in early life has the potential to delay sensitization and to reduce the risk that severe asthma will develop.

House-dust mites. House-dust mites are the most important documented risk factor for airway hyperresponsiveness (AHR) and asthmatic symptoms [24-26], and the severity of sensitization which develops is directly related to exposure levels [27, 28]. Exposure levels also influence the severity of asthma as measured by medication requirements [29], peak flow variability [30], and risk of admission to hospital [31-33]. This relationship occurs even in regions where allergen levels are quite low [34, 35], which suggests that there is no safe threshold.

House-dust mites are especially important in the aetiology of asthma because they are ubiquitous and occur perennially, and because they release proteases which are particularly potent allergens. House-dust mite levels are directly related to ambient levels of outdoor humidity [27], to air exchange rate and indoor humidity [36, 37], to damp and the amount of furnishings [38], to the regularity with which furnishings are laundered [39], and to a low ventilation rate, which increases indoor humidity [40-42].

Recent studies have demonstrated a dose-response relationship between exposure to house-dust mite allergens and several markers of asthma severity, including AHR, symptom severity and lung function. In a study of six random population samples of children, we conservatively estimated that there is a doubling in risk of children having current asthma for every doubling of Dermatophagoides pteronyssinus antigen I (Der p I) level [27], but the data could be less conservatively interpreted to indicate a quadrupling of risk at exposure levels above $10 \mu \mathrm{g} \cdot \mathrm{g}$ dust $^{-1}$. Similarly, a study of asthmatics in the UK found that there was a onefold increase in AHR for every twofold increase in Der $p$ I level [26]. Together with the evidence that relatively small changes in allergen exposure levels influence the degree of AHR and the severity of symptoms [43], these data suggest that even modest reductions in house-dust mite allergen levels will lead to a significant reduction in the severity of asthma.

Other indoor allergens. Indoor allergens from pets, cockroaches and moulds can also play an important role. In the USA, New Zealand and the UK, pets, particularly cats, are a well recognized source of domestic allergens which are associated with asthma [25, 32, 33, 44] and, in regions with low house-dust mite allergen levels, cat and dog allergens become a major cause of sensitization associated with asthma [45]. Levels of sensitization to cat allergens in children have been related to the cumulative duration of exposure [46].

Outdoor allergens. Outdoor allergens, such as Alternaria mould spores and ryegrass pollens, have a primary importance in the aetiology of asthma in dry agricultural regions and have been documented as causing acute exacerbations of severe illness [47-51]. Alternaria is the only allergen which has been reported to cause respiratory arrest [51]. Levels of Alternaria and ryegrass allergens are often determined by local agricultural and crop management practices, and peaks in exposure levels can occur under specific meteorological and seasonal conditions.

\section{Environmental tobacco smoke}

The effects of environmental tobacco smoke (ETS), which is the most common indoor air pollutant, on the respiratory health of children has been scientifically reviewed [52]. Mothers who smoke during pregnancy or parents who smoke in the same indoor environment as their child approximately double the risk of the child having a serious respiratory infection, such as pneumonia, bronchiolitis or bronchitis, in infancy which requires hospitalization [53-60] or treatment by a doctor [61-70]. Such infections are, in themselves, a risk factor for the later development of asthma [71-75], but it is not known whether they lead to the development of asthma or are the first expression of an asthmatic phenotype. There is evidence that exposure to ETS increases the risk of wheeze in infants and children, with an odds ratio of approximately $1.5-3.0$ [59, 63, 70, 76-82].

The effects of smoking during pregnancy, which is associated with preterm delivery and low birthweight $[83$, 84], and of postnatal exposure to ETS, which may compound the effects of prenatal exposure, have not been separated. Children with a low birthweight are at risk of having narrow airways and/or early respiratory symptoms [56, 84-88], and of developing allergic sensitization or wheeze in early childhood [70, 76, 78, 89, 90]. Studies conducted in China, where few women smoke, suggest that the effects of exposure to ETS in infancy are different from those of maternal smoking during pregnancy $[54,55]$. Animal studies, which are the only type of study able to separate out the pre- and postnatal effects, suggest that both types of exposure independently facilitate mechanisms which promote the development of AHR [91, 92]. 


\section{Dietary factors}

It has been hypothesised that dietary changes have contributed to a higher prevalence of asthma in affluent countries $[93,94]$. Several dietary factors, including a higher consumption of processed foods, omega- 6 oils and salt, and a lower consumption of omega- 3 fatty acids and fresh foods plus lower rates of breast-feeding, are all implicated because of their potential influence on inflammatory reactions. However, there have been relatively few epidemiological studies, which have examined the effects of diet, and most have been in adults whose airways may be less responsive to dietary factors. A deficient diet may increase susceptibility to adverse environmental exposures, such as allergens, ETS and infections, and, conversely, a "healthy" diet may protect against the effects of such exposures. It is also possible that dietary effects are larger than have been estimated from population studies in which the analyses have not been limited to a susceptible subgroup, such as children whose airways are still developing, atopics who are most at risk for the development of asthma, or subjects with prior respiratory symptoms.

Fatty acids. Circumstantial and epidemiological evidence suggests that consumption patterns of omega- 3 and omega- 6 fatty acids influence the development of airway inflammation. Omega-3 fatty acids, which are stored in cell membranes, have an important role in controlling inflammation [95], but are easily replaced by omega-6 fatty acids, which facilitate the development of inflammation. Omega-3 fatty acids are found in high quantities in fish oil and in monounsaturated oils, such as canola oil, whereas omega- 6 fatty acids are found in polyunsaturated fats, such as safflower and sunflower oils, which have been consumed in increasing amounts in recent years following campaigns to reduce heart disease. The twofold increase in the prevalence of childhood asthma in Australia has coincided with an eightfold increase in the ratio of consumption of butter (which contains omega-3 fatty acids) to polyunsaturated margarine $[93,96]$.

In population studies of children, we found that children who eat fish more than once a week, and who, therefore, consumed larger amounts of omega-3 fatty acids, were $30-70 \%$ less likely to have asthma than children who ate fish less often $[22,75]$. We confirmed this association in a more recent study using a food frequency questionnaire, in which we found that children who ate oily fish regularly were protected against asthma with an odds ratio of 0.3 (95\% confidence interval $(95 \% \mathrm{CI})$ $0.1-0.7)$ [97]. There was no difference in nonoily fish consumption between asthmatics and nonasthmatics, which suggests that parents of asthmatic children do not selectively prevent them from eating fish.

It is thought that asthma and other inflammatory diseases have a low prevalence in Greenland Eskimos because of their high fish intake [98]. In Mediterranean countries, where olive oil, which is low both in omega-3 and omega- 6 fatty acids, is commonly used, the prevalence of AHR in children is also low [99]. Dietary fish oil has also been shown to protect against coronary heart disease in middle-aged and elderly people [100], and against the development of airway narrowing [101, 102], chronic airflow limitation in smokers [103], and other diseases with an inflammatory component [104-106].

Electrolytes. Because sodium is implicated in many aspects of the regulation of smooth muscle tone, a diet with a high salt content is thought to predispose towards the development of airway disease. BuRnEY [107] first suggested a circumstantial link between increased salt intake and mortality from asthma, and BURNEY et al. [108] went on to show a close relationship between salt excretion and AHR in males. A gender difference in the importance of salt intake is plausible because animal and skeletal studies show gender differences in sodium metabolism which may influence muscle tone [109].

Further evidence comes from studies which have found a significant association between salt intake and AHR in subjects aged 9-16 yrs [110], and in adult males [111]. A study of males in the USA found a relationship between potassium and AHR, but found no influence of sodium intake [112]; and a study in the UK found a small relationship between dietary sodium and airways responsiveness in only one of three study samples [113]. Only two studies have enrolled both males and females. In Britain, no association was found between $24 \mathrm{~h}$ sodium urinary excretion and AHR in males and females [114] and, in the USA, both the level of potassium and the ratio of sodium to potassium were found to predict wheeze and bronchitis in adults [115]. Discrepancies between studies may result from problems with misclassification because dietary intakes are variable and inherently difficult to quantify, or from the inadequacy of the measurement of salt excretion as a marker of total dietary salt intake over a prolonged period.

Magnesium may also influence airway disease because it is involved in maintaining the electrical potential across cell membranes and may, therefore, have a bronchodilator effect on the airways. A population study in the UK found that, after adjusting for major confounders, such as atopy, age, sex and smoking history, magnesium intake had a significant association with measurements of AHR, forced expiratory volume in one second (FEV1) and selfreported wheeze [116].

Anti-oxidant vitamins. Antioxidant vitamins are the firstline of defence against oxygen free radicals, that are capable of damaging cellular components and which contribute to inflammation. It is hypothesized that a diet which is low in antioxidants, such as vitamins $\mathrm{A}$ and $\mathrm{C}$, may reduce natural defences and increase susceptibility to oxidant attack and airway inflammation [94]. There is evidence from two population studies of adults living in the UK that a diet with a low intake of fresh fruit and vegetables is a risk factor for decreased lung function [117, 118], but studies in the USA and in the Netherlands have found no relationship between low vitamin A intake and the degree of airway obstruction as assessed by various measures of lung function, even though detailed diaries were used to estimate dietary exposures $[119,120]$. In a study of females over a 10 year period, no association was found between antioxidant intake and the presence of asthma [121]. Although there was a suggestion that vitamin $\mathrm{E}$ had a modest protective effect, the trial was complicated by the fact that females who were at high risk of having asthma had supplemented their diet with vitamins $\mathrm{C}$ and $\mathrm{E}$. 
Breast-feeding. Breast-feeding is a source of immunoglobulin $\mathrm{A}(\operatorname{Ig} \mathrm{A})$, which has an anti-infective action and may prevent epithelial damage from respiratory infections. Thus, breast-feeding may have a beneficial effect because it postpones the age at which respiratory infection first occurs or because infants are protected from the foreign proteins present in cow's milk, which can increase allergic symptoms [122]. Infants who are breastfed have lower serum IgE levels [123], and have less allergic illness in early childhood [124-129] and through to adolescence [130]. Breast-fed infants have also been found to have less sensitization to house dust-mites at the age of $1 \mathrm{yr}$ [131], and fewer respiratory symptoms [132].

\section{Respiratory infections}

The role of viral and bacterial respiratory infections in the development of asthma is complicated. It has been hypothesized that bacterial infections in the first few weeks of life protect against the development of an allergic phenotype. Thus, it is thought that decreased exposure to infections in the first few weeks of life as a result of smaller family sizes and better hygiene has played a part in the higher prevalence of asthma in affluent populations. In Europe, small family size is associated with increased rates of atopy and allergic symptoms, with the first born children being at highest risk [133, 134]. Respiratory infections in early life may downregulate the production of $\mathrm{IgE}$ by influencing the development of a predominantly type 1 or type 2 T-helper (Th- 1 or Th-2) response. Viral infections may activate a Th-1 profile and, by preventing the proliferation of Th- 2 cell populations, protect against later allergic responses and the development of sensitization $[135,136]$.

However, there is also evidence that serious respiratory infections in early life are associated with the later development of asthma [59, 71, 73, 75, 137]. This suggests that early bacterial infections may protect against the development of atopy, whereas viral infections may provoke the first expression of asthma or may increase the risk of later asthma by causing airway inflammation or by facilitating allergens to cross the airway epithelium.

\section{Characteristics of "at-risk" groups}

The characteristics of children who are most at risk for the development of asthma and who need to be targeted for interventions are documented. Children who have a parent with asthma or an allergic illness are easily identified as being at risk of developing a similar illness [138-140], but cord IgE levels are not sensitive predictors of later asthma [123]. Children who have serious respiratory infection in early life [75], or who acquire sensitization to common allergens at an early age [21], are also at significant risk of having asthma in later childhood. Boys are at greater risk in that they have higher levels of atopy, AHR, symptoms and hospitalizations for asthma during childhood [141-144], and are more sensitive to changes in asthma severity with dietary salt intake [109].

Longitudinal studies show that children who develop a high level of sensitization to house-dust mite allergens are at the greatest risk of having a diagnosis of asthma, and of having reduced lung function and morbidity which has a significant impact on lifestyle [19, 22, 145]. Other "at-risk" groups include children who are exposed to ETS in utero or in early life, and children who have a low birthweight, who are not breast-fed, or who have a low omega-3 fatty acid or antioxidant vitamin intake. A 25 year longitudinal study found that frequent episodes of asthmatic symptoms and poor lung function in childhood predicted ongoing asthma in adulthood [146]. In subjects who are potentially susceptible to asthma, modifications in diet and in exposure to allergens and to ETS in early life are likely to be highly effective strategies for preventing and reducing morbidity caused by asthma.

\section{Strategies for prevention}

There are both occupational and experimental models which demonstrate that avoidance of a relevant environmental factor can reduce asthma morbidity, and that preventive strategies for asthma can be successful. Because environmental interventions may have little effect once asthma has become a chronic condition, interventions which commence in early life, or during early exposure, have the greatest potential. Interventions have mainly been tested as a method for reducing morbidity in patients who have already developed asthma, but they are likely to have a far greater potential as a method for preventing susceptible children from developing asthma in the first instance.

\section{Environmental and occupational models}

In Barcelona, many people developed sensitization to soya beans following intermittent exposure to small amounts of soya bean dust, which was generated from the unloading of ships in the harbour [147, 148]. Under certain atmospheric conditions, which occurred only infrequently, the city was exposed to high levels of soya bean dust, with a consequent significant increase in the number of patients attending hospital with acute exacerbations of symptoms. However, the installation of efficient silo filters has prevented ongoing intermittent high exposures and has eliminated further epidemics of asthma hospitalizations [149].

An encouraging model of avoidance is also provided by occupational exposure to Western red cedar. Some workers become sensitized to Western red cedar and develop respiratory symptoms [150], but their asthma abates if they then avoid exposure. However, continued exposure leads to the development of a chronic condition, which cannot be improved with avoidance [151, 152]. These models suggest that respiratory illness can be prevented or moderated at an early stage of the disease by protection from clinically relevant exposures but may not be easily prevented once a chronic condition is established.

\section{Allergen avoidance}

House-dust mite allergens. Avoidance of house-dust mite allergens has the most potential to reduce asthma in humid 
regions. House-dust mites thrive in places with sufficient humidity [37], and their proliferation can be prevented by depriving them of moisture. Indoor humidity levels can be reduced by dehumidifiers [153], by increased ventilation in bathrooms and kitchens and by removal of other sources of humidity, such as fish tanks. In practice, the control of indoor humidity requires many techniques, including changes in the use of heating, ventilation and air-conditioning systems. In the long-term, better housing design will be required to maintain low humidity environments in order to prevent the accumulation of allergens in furniture and bedding [154].

Many studies have concentrated on removing allergens from floors. Laundering mats and rugs or exposing them to sun for extended periods can kill mites but does not remove allergens [154]. Reductions in allergen levels in soft floor coverings can be achieved in the short-term with acaracides [155], but their effect on long-term reduction remains contradictory [156-159]. Moreover, the clinical importance of measures which address only floor levels remains debatable because the most clinically relevant source of house-dust mites is from the bed, presumably because the airways are in close proximity to the allergen source for extended periods of time [27].

Allergen levels in beds can be reduced relatively easily by covering mattresses with occlusive covers [42, 160], by regular washing and by regular replacement of pillows, which can be cheaper and more comfortable than covering with occlusive materials. In regions where allergen levels are high, a very active strategy may be required [157]. Cleaning of toys, curtains and soft furnishings is also important because they can harbour huge amounts of allergens [154]. It is encouraging that there are wide variations in $\operatorname{Der} p$ I levels in climates that favour the growth of house-dust mites [161], and that low levels have been recorded in public places in regions where domestic levels are high [162, 163] because this endorses the feasibility of attaining low allergen levels in humid climates.

Removal of house-dust mite sensitized children to a low allergen environment decreases their AHR and improves symptoms [164-166]. However, the low allergen environment needs to be maintained long-term because AHR returns to former levels when the children return to higher exposures [167], although treatment with budesonide can prevent this [168]. Allergen avoidance together with effective treatment may achieve the greatest benefits for children who have already developed AHR.

A controlled intervention trial with blinded assessments of an "at-risk" birth cohort has successfully demonstrated that a significant reduction in the incidence of asthma can be attained [128, 169-171]. In this trial, several dietary and house-dust mite avoidance interventions were undertaken simultaneously so that the separate effects are not known, but it is encouraging that children who underwent active intervention had significantly less sensitization to allergens at the age of $1 \mathrm{yr}$, and significantly less asthma at the age of 2 yrs.

Cat allergens. The cat allergen ( Fel $d$ I) from the sebaceous glands and saliva, which dries on the pelt, can be carried on very small particles which remain airborne for long periods, or continuously [172]. After eviction of a cat, it can take more than 6 months for airborne Fel $d$ I levels to return to levels comparable with cat-free homes [173]. Limiting the cat to living outdoors will reduce exposure but, for people who refuse this, measures such as weekly washing of the cat, hard floors, the presence of minimal furnishings and increased ventilation rates can help to maintain low airborne allergen levels [38], although it is unlikely that these are practical. Significant exposures to cat allergens can also occur in schools and public buildings [39, 174, 175].

Outdoor allergens. Because outdoor allergens are not easily avoided, a lateral approach to prevent both sensitization and symptoms will be required, and may involve both optimal medical management and filtration of incoming air. For young children who experience episodic symptoms, treatment with preventive medications solely during periods of critical exposure has the potential to prevent AHR or symptoms from increasing in severity, although there are no reported studies of this approach. For people who spend a considerable amount of time at home, such as infants and the elderly, air-conditioning systems or indoor air cleaners with a high efficiency particulate (HEPA)-filter have the potential to reduce exposure to allergens which blow indoors but this also has not been tested, although filters which reduce airborne particulate matter were shown to be effective in reducing symptoms of rhinitis and asthma in a clinical trial in the USA [176].

\section{Environmental tobacco smoke}

Avoidance of early exposure to ETS will prevent the subsequent outcome of an increased risk of a serious respiratory infection in infancy. The ban on smoking in public places has generally reduced exposure to ETS in the community but ETS in the home, which is the predominant place of exposure for many young children, has not been fully addressed. Moreover, smoking rates in young adult females have not changed substantially over the last decade and have not mirrored declining rates of smoking by males, which suggests that educational campaigns need to focus on young mothers or those planning to have children.

\section{Dietary interventions}

Fatty acids. Several clinical trials have investigated the effects of supplementation with fish oils on asthma and most show that the omega-3 fatty acids are incorporated into cell membranes and reduce the production of leukotrienes and cytokines, which are involved in inflammatory processes [177-181]. However, no clinical improvement in the severity of asthma has been demonstrated, perhaps because the trial periods were only 8-10 weeks and longer periods may be required before an expected anti-inflammatory effect in the airways is sufficient to reduce symptom severity. Although one study found that episodic asthma did not improve after 6 months of supplementation [180], another study of 9 months of supplementation found significant increases in FEV1 [181].

Salt and antioxidant intake. The clinical benefits of altering salt intake are uncertain. In a small open study, 
doubling of salt intake for 1 month resulted in a modest increase in AHR [182], but an open, randomized 2 week trial was unable to demonstrate an effect of altered salt intake on the severity of asthma as assessed by peak expiratory flow rate or beta-agonist use, even though good compliance was confirmed by measurements of sodium excretion [183]. However, the patients were mild asthmatics and self-monitored peak expiratory flow rates are not a sensitive indicator of AHR or symptom severity. Larger studies with a stronger design and longer periods of salt intake have been more encouraging. A study of asthmatic males, who were established on a low sodium diet before being randomized to receive a slow sodium or placebo intake, found a relationship between salt intake and the clinical indicators of AHR, bronchodilator use, peak flow readings and AHR [184]. Also, a randomized, double-blind, cross-over trial in the UK found more severe AHR in males supplemented with sodium, but not in females [185].

\section{Economic implications}

Prevention of asthma has several economic implications. Ideally, environmental interventions will reduce use of medical services and asthma medications and will provide a cost-effective method for improving quality of life both for asthmatics and potential asthmatics. However, the costs of different interventions will vary considerably and some groups of asthmatics may require both intervention and optimal use of asthma medications to improve their condition. Interventions which address diet and exposure to ETS will be less expensive than avoidance of indoor allergens, which requires significant changes to the indoor environment and/or a major commitment to maintain.

It is difficult to judge the economic effectiveness of preventive strategies because there are few data relating to the costs and economic efficiency of current asthma management and there has been no assessment of the costs of prevention. We estimated that the total cost of asthma in New South Wales was \$209 million in 1989, of which $\$ 142$ million was spent on direct health care costs [15]. In a more recent study, the mean annual cost to the family of an asthmatic child outside of government Medicare costs was $\$ 212$, which rose to $\$ 884$ if the child had asthma which was severe enough to require admission to a hospital [17]. It seems reasonable to assume that interventions which are based on our current knowledge of risk factors could achieve a $50 \%$ reduction in the prevalence of asthma, and that this would be accompanied by a similar reduction in the costs of treatment and care.

\section{References}

1. Evans IR, Mullally DI, Wilson RW, et al. National trends in the morbidity and mortality of asthma in the US: prevalence, hospitalization and death from asthma over two decades, 1965-1984. Chest 1987; 91: 65S-74S.

2. Haahtela T, Lindholm H, Bjorksten F, Koskenvuo K, Laitinen LA. Prevalence of asthma in Finnish young men. BMJ 1990; 301: 266-268.

3. Burney PGJ, Chinn S, Rona RJ. Has the prevalence of asthma increased in children? Evidence from the national study of health and growth. 1973-1986. BMJ 1990; 300: $1306-1310$.

4. Robertson CF, Heycock E, Bishop J, Nolan T, Olinsky A, Phelan P. Prevalence of asthma in Melbourne schoolchildren: changes over 26 years. BMJ 1991; 302: 11161118 .

5. Peat JK, van den Berg RH, Green WF, Mellis CM, Leeder SR, Woolcock AJ. Changing prevalence of asthma in Australian children. BMJ 1994; 308: 1591-1596.

6. Nakagomi T, Itaya $\mathrm{H}$, Tominaga $\mathrm{T}$, Yamaki M, Hisamatsu $\mathrm{S}$, Nakagomi O (Letter). Is atopy increasing? Lancet 1994; 343: 121-122.

7. Robertson CF, Bishop J, Sennhauser FH, Mallol J. International comparison of asthma prevalence in children: Australia, Switzerland, Chile. Pediatr Pulmonol 1993; 16: 219-226.

8. Peat JK, Gray EJ, Mellis CM, Leeder SR, Woolcock AJ. Differences in airway responsiveness between children and adults living in the same environment: an epidemiological study in two regions of New South Wales. Eur Respir J 1994; 7: 1805-1813.

9. Burr ML, Limb ES, Andrae S, Barry DMJ, Nagel F. Childhood asthma in four countries: a comparative survey. Int J Epidemiol 1994; 23: 341-347.

10. von Mutius E, Martinez FD, Fritzsch C, Nicolai T, Roell G, Thiemann H-H. Prevalence of asthma and atopy in two areas of West and East Germany. Am J Respir Crit Care Med 1994; 149: 358-364.

11. Leeder SR. The contribution of epidemiology to the definition of health goals and targets for Australia. Int $J$ Epidemiol 1995; 24 (Suppl.): S109-S112.

12. Woolcock AJ, Peat JK. Epidemiology of asthma in Australia. ACMA J 1995; 1: 5-7.

13. Kun HY, Oates RK, Mellis CM. Hospital admissions and attendances for asthma: a true increase? Med J Aust 1993; 159: 312-313.

14. Peat JK, Toelle BG, Gray EJ, et al. Prevalence and severity of childhood asthma and allergic sensitisation in seven climatic regions of New South Wales. Med J Aust 1995; 163: 22-26.

15. Mellis CM, Peat JK, Bauman A, Woolcock AJ. The cost of asthma in New South Wales. Med J Aust 1991; 155: 522-528.

16. Weiss KB, Gergen PJ, Hodgson TA. An economic evaluation of asthma in the United States. $N$ Engl J Med 1992; 326: 862-866.

17. Toelle BG, Peat JK, Mellis CM, Woolcock AJ. The cost of childhood asthma to Australian families. Pediatr Pulmonol 1995; 19: 330-335.

18. Burrows B, Martinez FD, Halonen M, Barbee RA, Cline MG. Association of asthma with serum IgE levels and skin test reactivity to allergens. $N$ Engl J Med 1989; 320: 271-277.

19. Sears MR, Burrows B, Herbison GP, Holdaway MD, Flannery EM. Atopy in childhood. II. Relationship to airway responsiveness, hay fever and asthma. Clin Exp Allergy 1993; 23: 949-956.

20. Holt PG, McMenamin C, Nelson D. Primary sensitisation to inhalant allergens during infancy. Pediatr Allergy Immunol 1990; 1: 3-13.

21. Peat JK, Salome CM, Woolcock AJ. Longitudinal changes in atopy during a 4 year period: relation to bronchial hyperresponsiveness and respiratory symptoms in a population sample of Australian schoolchildren. I Allergy Clin Immunol 1990; 85: 65-74.

22. Peat JK, Tovey E, Gray EJ, Mellis CM, Woolcock AJ. 
Asthma severity and morbidity in a population sample of Sydney schoolchildren: Part II. Importance of house dust mite allergens. Aust NZ J Med 1994; 24: 270276.

23. Sporik R, Holgate ST, Platts-Mills TAE, Cogswell JJ. Exposure to house-dust mite allergen (Der $p$ I) and the development of asthma in childhood: a prospective study. N Engl J Med 1990; 323: 502-507.

24. Sporik R, Chapman MD, Platts-Mills TAE. House-dust mite exposure as a cause of asthma. Clin Exp Allergy 1992; 22: 897-906.

25. Sears MR, Burrows B, Flannery EM, Herbison GP, Holdaway MD. Atopy in childhood. I. Gender and allergen related risks for development of hay fever and asthma. Clin Exp Allergy 1993; 23: 941-948.

26. Custovic A, Taggart SCO, Francis HC, Chapman MD, Woodcock A. Exposure to house-dust mite allergens and the clinical activity of asthma. J Allergy Clin Immunol 1996; (in press).

27. Peat JK, Tovey ER, Toelle BG, et al. House-dust mite allergens: a major risk factor for childhood asthma in Australia. Am J Respir Crit Care Med 1996; 152: 144146.

28. Charpin D, Kleisbauer JP, Lanteaume A, et al. Asthma and allergy to house-dust mites in populations living in high altitudes. Chest 1988; 93: 758-761.

29. Vervloet D, Charpin D, Haddi E, et al. Medication requirements and house-dust mite exposure in mite-sensitive asthmatics. Allergy 1991; 46: 554-558.

30. Zock JP, Brunekreef B, Hazebrook-Kampschreur AAJM, Roosjen CW. House-dust mite allergen in bedroom floor dust and respiratory health of children with asthmatic symptoms. Eur Respir J 1994; 7: 1254-1259.

31. Sporik R, Platts-Mills TAE, Cogswell JJ. Exposure to house-dust mite allergen of children admitted to hospital with asthma. Clin Exp Allergy 1993; 23: 740-746.

32. Gelber LE, Seltzer LH, Bouzoukis JK, Pollart SM, Chapman MD, Platts-Mills TAE. Sensitization and exposure to indoor allergens as risk factors for asthma among patients presenting to hospital. Am Rev Respir Dis 1993; 147: 573-578.

33. Pollart SM, Chapman MD, Fiocco GP, Rose G, Platts MT. Epidemiology of acute asthma: IgE antibodies to common inhalant allergens as a risk factor for emergency room visits. J Allergy Clin Immunol 1989; 83: 875-882.

34. Wickman M, Nordvall SL, Pershagen G, Sundell J, Schwartz B. House-dust mite sensitization in children and residential characteristics in a temperate region. $J$ Allergy Clin Immunol 1991; 88: 89-95.

35. Bjornsson E, Norback D, Janson C, et al. Asthmatic symptoms and indoor levels of microorganisms and housedust mites. Clin Exp Allergy 1995; 25: 423-431.

36. Harving H, Korsgaard J, Dahl R. House-dust mite exposure reduction in specially designed, mechanicallyventilated "healthy" homes. Allergy 1994; 49: 713-718.

37. Arlian LG. Water balance and humidity requirements of house-dust mites. Exp Appl Acarol 1992; 16: 15-35.

38. de Blay F, Chapman MD, Platts-Mills TAE. Airborne cat allergen ( $F$ el $d \mathrm{I}$ ): environmental control with the cat in situ. Am Rev Respir Dis 1991; 143: 1334-1339.

39. Munir AKM, Einarsson R, Dreborg SKG. Mite (Der $p$ I, Der $f \mathrm{I})$, cat $(F e l d \mathrm{I})$ and $\operatorname{dog}($ Can $f \mathrm{I})$ allergens in dust from Swedish day-care centres. Clin Exp Allergy 1995; 25: 119-126.

40. Harving H, Korsgaard J, Dahl R. House-dust mites and associated environmental conditions in Danish homes. Allergy 1993; 48: 106-109.
41. Wickman M, Emenius G, Egmar A-C, Axelsson G, Pershagen G. Reduced mite allergen levels in dwellings with mechanical exhaust and supply ventilation. Clin Exp Allergy 1994; 24: 109-114.

42. Wickman M, Nordvall SL, Pershagen G, Korsgaard J, Johansen N, Sundell J. Mite allergens during 18 months of intervention. Allergy 1994; 49: 114-119.

43. van der Heide S, de Monchy JGR, de Vries K, Bruggnik TM, Kauffman HF. Seasonal variation in airway hyperresponsiveness and natural exposure to house-dust mite allergens in patients with asthma. J Allergy Clin Immunol 1994; 93: 470-475.

44. Warner JA, Little SA, Pollock I, Longbottom JL, Warner JO. The influence of exposure to house-dust mite, cat pollen and fungal allergens in the home on primary sensitisation in asthma. Pediatr Allergy Immunol 1990; 1: 79-86.

45. Sporik R, Ingram MJ, Price W, Sussman JH, Honsinger RW, Platts-Mills TAE. Association of asthma with serum $\operatorname{IgE}$ and skin test reactivity to allergens among children living at high altitude: tickling the dragon's breath. $\mathrm{Am}$ J Respir Crit Care Med 1995; 151: 1388-1392.

46. Desjardins A, Benoit $\mathrm{C}$, Ghezzo $\mathrm{H}$, et al. Exposure to domestic animals and risk of immunologic sensitization in subjects with asthma. J Allergy Clin Immunol 1993; 91: 979-986.

47. Bellomo R, Gigliotti P, Treloar A, et al. Two consecutive thunderstorm-associated epidemics of asthma in the city of Melbourne. The possible role of rye grass pollen. Med J Aust 1992; 156: 834-837.

48. Suphioglu C, Singh MB, Taylor P, et al. Mechanism of grass pollen-induced asthma. Lancet 1992; 339 569572.

49. Peat JK, Tovey E, Mellis CM, Leeder SR, Woolcock AJ. Importance of house dust mite and Alternaria allergens in childhood asthma: an epidemiological study in two climatic regions of Australia. Clin Exp Allergy 1993; 23: 812-820.

50. Knox RB. Grass pollen, thunderstorms and asthma. Clin Exp Allergy 1993; 23: 354-359.

51. O'Hollaren MT, Yunginger JW, Offord KP, et al. Exposure to an aeroallergen as a possible precipitating factor in respiratory arrest in young patients with asthma. $N$ Engl J Med 1991; 324: 359-363.

52. United States Environmental Protection Agency. Respiratory health and effects of passive smoking: lung cancer and other disorders. In: Office of Research and Development RD-689, Washington DC, 1992.

53. Ekwo EE, Weinberger MM, Lachenbruch PA, Huntley WH. Relationship of parental smoking and gas cooking to respiratory disease in children. Chest 1983; 84: 662-668.

54. Chen Y, Wanxian L, Shunzhang Y. Influence of passive smoking on admissions for respiratory illness in early childhood. BMJ 1986; 293: 303-306.

55. Chen Y, Li W, Yu S, Qian W. Chang-Ning Epidemiological study of children's health. I. Passive smoking and children's respiratory diseases. Int J Epidemiol 1988; 17: 348-355.

56. Chen Y. Environmental tobacco smoke, low birth weight, and hospitalization for respiratory disease. Am J Respir Crit Care Med 1994; 150: 54-58.

57. Taylor B, Wadsworth J. Maternal smoking during pregnancy and lower respiratory tract illness in early life. Arch Dis Child 1987; 62: 786-791.

58. Anderson LJ, Parker RA, Strikas RA, et al. Day-care center attendance and hospitalization for lower respiratory tract illness. Pediatrics 1988; 82: 300-308. 
59. Stern B, Raizenne M, Burnett R. Respiratory effects of early childhood exposure to passive smoke. Environ Int 1989; 15: 29-34.

60. Weitzman M, Gortmaker S, Walker DK, Sobol A. Maternal smoking and childhood asthma. Pediatrics 1990; 85: 505-511.

61. Colley JRT, Holland WW, Corkhill RT. Influence of passive smoking and parental phlegm on pneumonia and bronchitis in early childhood. Lancet 1974; 1: 1031-1034.

62. Leeder SR, Corkhill R, Irwig LM, Holland WW, Colley JRT. Influence of family factors on the incidence of lower respiratory illness in the first year of life. $\mathrm{Br} J$ Prev Soc Med 1976; 30: 203-212.

63. Fergusson DM, Horwood LJ, Shannon FT. Parental smoking and respiratory illness in infancy. Arch Dis Child 1980; 55: 358-361.

64. Fergusson DM, Horwood LJ, Shannon FT, Taylor B. Parental smoking and lower respiratory illness in the first three years of life. J Epidemiol Commun Health 1981; 35: $180-184$.

65. Schenker MB, Samet JM, Speizer FE. Risk factors for childhood respiratory disease: the effect of host factors and home environmental exposures. Am Rev Respir Dis 1983; 128: 1038-1043.

66. Fergusson DM, Horwood LJ. Parental smoking and respiratory illness during early childhood: a six year longitudinal study. Pediatr Pulmonol 1985; 1: 99-106.

67. Pedreira FA, Guandolo VL, Feroli EJ, Melia GW, Weiss IP. Involuntary smoking and incidence of respiratory illness during the first year of life. Pediatr 1985; 75: 594-597.

68. McConnochie KM, Roghmann KJ. Parental smoking, presence of older siblings, and family history of asthma increase risk of bronchiolitis. Am J Dis Child 1986; 140: 806-812.

69. Forastiere F, Corbo GM, Michelozzi P, et al. Effects of environment and passive smoking on the respiratory health of children. Int J Epidemiol 1992; 21: 66-73.

70. Rylander E, Pershagen G, Eriksson M, Nordvall L. Parental smoking and other risk factors for wheezing bronchitis in children. Eur J Epidemiol 1993; 9: 517-526.

71. Weiss ST, Tager IB, Munoz A, Speizer FE. The relationship of respiratory infections in early childhood to the occurrence of increased levels of bronchial responsiveness and atopy. Am Rev Respir Dis 1985; 131: 573-578.

72. Cogswell JJ, Halliday DF, Alexander JR. Respiratory infections in the first year of life in children at risk of developing atopy. BMJ 1982; 284: 1011-1013.

73. Voter KZ, Henry MM, Stewart PW, Henderson FW. Lower respiratory illness in early childhood and lung function and bronchial reactivity in adolescent males. Am Rev Respir Dis 1988; 137: 302-307.

74. Gurwitz D, Mindorff C, Levison H. Increased incidence of bronchial reactivity in children with a history of bronchiolitis. J Pediatr 1981; 98: 551-555.

75. Peat JK, Salome CM, Woolcock AJ. Factors associated with bronchial hyperresponsiveness in Australian adults and children. Eur Respir J 1992; 5: 921-929.

76. Bisgaard H, Dalgaard P, Nyboe J. Risk factors for wheezing during infancy: a study of 5,953 infants. Acta Paediatr Scand 1987; 76: 719-726.

77. Burr ML, Miskelly FG, Butland BK, Merrett TG, VaughanWilliams E. Environmental factors and symptoms in infants at high risk of allergy. J Epidemiol Commun Health 1989; 43: 125-132.

78. Halken S, Host A, Husby S, Hansen LG, Osterballe O, Nyboe J. Recurrent wheezing in relation to environmental risk factors in infancy. Allergy 1991; 46: 507-514.
79. Somerville SM, Rona RJ, Chinn S. Passive smoking and respiratory conditions in primary school children. $J$ Epidemiol Commun Health 1988; 42: 105-110.

80. Burchfiel CM, Higgins MW, Keller JB, Howatt WF, Butler WJ, Higgins ITT. Passive smoking in childhood: respiratory conditions and pulmonary function in Tecumseh, Michigan. Am Rev Respir Dis 1986; 133: 966-973.

81. McConnochie KM, Roghmann KJ. Wheezing at 8 and 13 years: changing importance of bronchiolitis and passive smoking. Pedriatr Pulmonol 1989; 6: 138-146.

82. Shaw R, Woodman K, Crane J, Moyes C, Kennedy J, Pearce N. Risk factors for asthma symptoms in Kawerau children. NZ Med J 1994; 107: 387-391.

83. Conter V, Cortinovis I, Rogari P, Riva L. Weight growth in infants born to mothers who smoked during pregnancy. BMJ 1995; 310: 768-771.

84. Kelly YJ, Brabin BJ, Milligan P, Heaf DP, Reid J, Pearson MG. Maternal asthma, premature birth, and the risk of morbidity in schoolchildren in Merseyside. Thorax 1995; 50: 525-530.

85. Martinez FD, Morgan WJ, Wright AL, et al. Diminished lung function as a predisposing factor for wheezing respiratory illness in infants. $N$ Engl J Med 1988; 319: 1112-1117.

86. Frischer T, Kuehr J, Meinert R, et al. Relationship between low birth weight and respiratory symptoms in a cohort of primary school children. Acta Paediatr 1992; 81: 1040-1041.

87. Kitchen WH, Olinsky A, Doyle LW, et al. Respiratory health and lung function in 8 year old children of very low birth weight: a cohort study. Pediatr 1992; 89: 1151-1158.

88. Giffin F, Greenough A, Yuksel B. Relationship between lung function results in the first year of life and respiratory morbidity in early childhood in patients born prematurely. Pediatr Pulmonol 1994; 18: 290-294.

89. Kuehr J, Frischer T, Karmaus W, et al. Early childhood risk factors for sensitization at school age. J Allergy Clin Immunol 1992; 90: 358-363.

90. Chan KN, Elliman A, Bryan E, Silverman M. Respiratory symptoms in children of low birth weight. Arch Dis Child 1989; 64: 1294-1304.

91. Lai Y-L, Thacker A, Gairola CG. Sidestream cigarette smoke exposure and airway reactivity during early life. J Appl Physiol 1994; 77: 1868-1874.

92. Joad JP, Bric JM, Kott KS. Effects of chronic side-stream smoke exposure in utero and/or postnatally on airway function and reactivity to methacholine in rats. $A m J$ Respir Crit Care Med 1994; 149: A392.

93. Hodge L, Peat JK, Salome C. Increased consumption of polyunsaturated oils may be a cause of increased prevalence of childhood asthma. Aust NZ J Med 1994; 24: 727.

94. Seaton A, Godden DJ, Brown K. Increase in asthma: a more toxic environment or a more susceptible population? Thorax 1994; 49: 171-174.

95. Ritter JM, Taylor GW. Fish oil in asthma. Thorax 1988; 43: 81-83.

96. NH \& MRC Working Party. The role of polyunsaturated fats in the Australian diet. Canberra, Australian Government Publishing Service, 1992;

97. Hodge L, Salome CM, Peat JK, Haby MM, Xuan W, Woolcock AJ. Consumption of oily fish and childhood asthma risk. Med J Aust 1996; 164: 137-140.

98. Horrobin DF. Low prevalences of coronary heart disease (CHD), psoriasis, asthma and rheumatoid arthritis in Eskimos: are they caused by high dietary intake of eicosapentaenoic acid (EPA), a genetic variation of essential 
fatty acid (EFA) metabolism or a combination of both? Med Hypotheses 1987; 22: 421-428.

99. Bardagi S, Agudo A, Gonzalez CA, Romero PV. Prevalence of exercise-induced airway narrowing in schoolchildren from a Mediterranean town. Am Rev Respir Dis 1993; 147: 1112-1115.

100. Kromhout D, Feskens EJM, Bowles CH. The protective effect of a small amount of fish on coronary heart disease mortality in an elderly population. Int J Epidemiol 1995; 24: 340-345.

101. Sharp DS, Rodriguez BL, Shahar E. Fish consumption may limit the damage of smoking on the lung. Am $J$ Respir Crit Care Med 1994; 150: 983-987.

102. Schwartz J, Weiss ST. The relationship of dietary fish intake to level of pulmonary function in the first National Health and Nutrition Examination Survey (NHANES 1). Eur Respir J 1994; 7: 1821-1824.

103. Britton J. Dietary fish oil and airways obstruction. Thorax 1995; 50: S11-S15.

104. Kremer JM, Jubiz W, Michalek A, et al. Fish oil fatty acid supplementation in active rhuematoid arthritis: a double-blinded, controlled, cross-over study. Ann Intern Med 1987; 106: 497-503.

105. Stenson WF, Cort D, Rodgers J, et al. Dietary supplementation with fish oil in ulcerative colitis. Ann Inten Med 1992; 116: 609-614.

106. Kojima T, Terano T, Tanabe E, Okamoto S, Tamura Y, Yoshida S. Long-term administration of highly purified eicosapentaenoic acid provides improvement of psoriasis. Dermatologica 1991; 182: 225-230.

107. Burney P. A diet rich in sodium may potentiate asthma: epidemiological evidence for a new hypothesis. Chest 1987; 91 (Suppl.): 143S-148S.

108. Burney PGJ, Britton JR, Chinn S, et al. Response to inhaled histamine and 24 hour sodium excretion. BMJ 1986; 292: 1483-1486.

109. Knox AJ. Salt and asthma. BMJ 1993; 307: 1159-1160.

110. Pistelli R, Forastiere F, Corbo GM, et al. Respiratory symptoms and bronchial responsiveness are related to dietary salt intake and urinary potassium excretion in male children. Eur Respir J 1993; 6: 517-522.

111. Tribe RM, Barton JR, Poston L, Burney PGJ. Dietary sodium intake, airway responsiveness, and cellular sodium transport. Am J Respir Crit Care Med 1994; 149: 1426-1433.

112. Sparrow D, O'Connor GT, Rosner B, Weiss ST. Methacholine airway responsiveness and 24 hour urine excretion of sodium and potassium: the normative aging study. Am Rev Respir Dis 1991; 144: 722-725.

113. Devereux G, Beach JR, Bromly C, et al. Effect of dietary sodium on airways responsiveness and its importance in the epidemiology of asthma: an evaluation in three areas of northern England. Thorax 1995; 50: 941-947.

114. Britton J, Pavord I, Richards K, et al. Dietary sodium intake and the risk of airway hyperreactivity in a random adult population. Thorax 1994; 49: 875-880.

115. Schwartz J, Weiss ST. Dietary factors and their relation to respiratory symptoms: the second National Health and Nutrition Examination survey. Am J Epid 1990; 132: 67-76.

116. Britton J, Pavord I, Richards K, et al. Dietary magnesium, lung function, wheezing, and airway hyperreactivity in a random adult population sample. Lancet 1994; 344: $357-362$.

117. Strachan D, Cox BD, Erzinclioglu SW, Walters DE, Whichelow MJ. Ventilatory function and winter fresh fruit consumption in a random sample of British adults. Thorax 1991; 46: 624-629.
118. Britton JR, Pavord ID, Richards KA, et al. Dietary antioxidant vitamin intake and lung function in the general population. Am J Respir Crit Care Med 1995; 151: 1383-1387.

119. Shahar E, Folsom AR, Melnick SL, et al. Does dietary vitamin A protect against airway obstruction. Am J Respir Crit Care Med 1994; 150: 978-982.

120. Miedema I, Feskens EJM, Heederik D, Kromhout D. Dietary determinants of long-term incidence of chronic nonspecific lung diseases. Am J Epid 1993; 138: 37-45.

121. Troisi RJ, Willett WC, Weiss ST, Trichopoulos D, Rosner B, Speizer FE. A prospective study of diet and adultonset asthma. Am J Respir Crit Care Med 1995; 151: 1401-1408.

122. Willems R, Duchateau J, Magrez P, Denis R, Casimir $\mathrm{G}$. Influence of hypoallergenic milk formula on the incidence of early allergic manifestations in infants predisposed to atopic diseases. Ann Allergy 1993; 71: 147-150.

123. Buonocore G, Zani S, Tomasini B, Tripodi V, Grano S, Bracci R. Serum IgE concentrations in the neonatal period. Biol Neonate 1992; 62: 10-14.

124. Businco L, Marchetti F, Pellegrini G, Cantani A, Perlini R. Prevention of atopic disease in "at-risk newborns" by prolonged breast-feeding. Ann Allergy 1983; 51: 296-299.

125. Geller-Bernstein G, Kenett R, Weisglass L, Tsur S, Lahav M, Levin S. Atopic babies with wheezy bronchitis. Allergy 1987; 42: 85-91.

126. Woodward A, Grgurinovich N, Ryan P. Breast feeding and smoking hygiene: major influences on cotinine in urine of smokers' infants. J Epidemiol Commun Health 1986; 40: 309-315.

127. Wright AL, Taussig LM, Ray CG, et al. The Tucson Children's Respiratory Study. II. Lower respiratory tract illness in the first year of life. Am J Epidemiol 1989; 129: $1232-1246$.

128. Arshad SH, Stevens M, Hide DW. The effect of genetic and environmental factors on the prevalence of allergic disorders at the age of two years. Clin Exp Allergy 1993; 23: 504-511.

129. Bardare M, Vaccari A, Allievi E, et al. Influence of dietary manipulation on incidence of atopic disease in infants at risk. Ann Allergy 1993; 71: 366-371.

130. Saarinen UM, Kajosari M. Breast-feeding as prophylaxis against atopic disease: prospective follow-up study until 17 years old. Lancet 1995; 346: 1065-1069.

131. Kramer MS. Does breast-feeding help protect against atopic disease? J Pediatr 1988; 112: 181-190.

132. Woodward A, Douglas RM, Graham NMH, Miles H. Acute respiratory illness in Adelaide children: breastfeeding modifies the effect of passive smoking. J Epidemiol Commun Health 1990; 44: 224-230.

133. von Mutius E, Martinez FD, Fritzsch C, Nicolai T, Reitmeir $\mathrm{P}$, Thiemann H-H. Skin test reactivity and number of siblings. BMJ 1994; 308: 692-695.

134. Strachan DP. Hay fever, hygiene, and household size. BMJ 1989; 299: 1259-1260.

135. Martinez FD. Role of viral infections in the inception of asthma and allergies during childhood: could they be protective? Thorax 1994; 49: 1189-1191.

136. Romagnani S. Human Th1 and Th2 subsets: regulation of differentiation and role in protection and immunopathology. Int Arch Allergy Appl Immunol 1992; 98: 279-285.

137. Busse WW. Respiratory infections: their role in airway responsiveness and the pathogenesis of asthma. J Allergy Clin Immunol 1990; 85: 671-683.

138. Duffy DL, Martin NG, Battistutta D, Hopper JL, Mathews JD. Genetics of asthma and hay fever in Australian twins. Am Rev Respir Dis 1990; 142: 1352-1358. 
139. Bjorksten B. Risk factors in early childhood for the development of atopic diseases. Allergy 1994; 49: 400-407.

140. Clough JB. Pre- and post-natal events leading to allergen sensitization. Clin Exp Allergy 1993; 23: 462-465.

141. Paoletti P, Carrozzi L, Viegi G, et al. Distribution of bronchial responsiveness in a general population: effect of sex, age, smoking, and level of pulmonary function. Am J Respir Crit Care Med 1995; 151: 1770-1777.

142. Martinez FD, Wright AL, Taussig LM, et al. Asthma and wheezing in the first six years of life. $N$ Engl J Med 1995; 332: 133-138.

143. Leung R, Bishop J, Robertson CF. Prevalence of asthma and wheeze in Hong Kong schoolchildren: an international comparative study. Eur Respir J 1994; 7: 2046-2049.

144. Crain EF, Weiss KB, Bijur PE, Hersh M, Westbrook L, Stein REK. An estimate of the prevalence of asthma and wheezing among inner-city children. Pediatrics 1994; 94 : 356-362.

145. Sears MR, Burrows B, Herbison GP, Flannery EM, Holdaway MD. Atopy in childhood. III. Relationship with pulmonary function and airway reponsiveness. Clin Exp Allergy 1993; 23: 957-963.

146. Jenkins MA, Hopper JL, Bowes G, Carlin JB, Flander LB, Giles GG. Factors in childhood as predictors of asthma in adult life. BMJ 1994; 309: 90-93.

147. Anto J, Sunyer J, Rodriguez-Roisin R, et al. Community outbreaks of asthma associated with inhalation of soybean dust. N Engl J Med 1989; 320: 1097-1102.

148. Sunyer J, Anto JM, Sabria J, et al. Risk factors of soybean epidemic asthma: the role of smoking and atopy. Am Rev Respir Dis 1992; 145: 1098-1102.

149. Anto JM, Sunyer J, Reed CE, et al. Preventing asthma epidemics due to soybeans by dust control measures. $N$ Engl J Med 1993; 329: 1760-1763.

150. Chan-Yeung K, Barton G, MacLean L, Grzyowski S. Occupational asthma and rhinitis due to western red cedar. Am Rev Respir Dis 1973; 108: 1094-1102.

151. Banks DE, Rando RJ, Barkman HJ. Persistence of toluene diisocyanate-induced asthma despite negligable workplace exposures. Chest 1990; 97: 121-125.

152. Mapp CE, Corona PC, De MN, Fabbri L. Persistent asthma due to isocyanates: a follow-up study of subjects with occupational asthma due to toluene diisocyanate (TDI). Am Rev Respir Dis 1988; 137: 1326-1329.

153. Cabrera P, Julia-Serda G, Rodriguez de Castro F, Caminero J, Barber D, Carrillo T. Reduction of house-dust mite allergens after dehumidifier use. J Allergy Clin Immunol 1995; 95: 635-636.

154. Tovey E. House-dust control measures: are they worthwhile? Mod Med Aust 1993; August: 118-127.

155. Woodfolk JA, Hayden ML, Miller JD, Rose G, Chapman MD, Platts-Mills TAE. Chemical treatment of carpets to reduce allergen: a detailed study of the effects of tannic acid on indoor allergens. J Allergy Clin Immunol 1994; 94: 19-26.

156. Tovey ER, Marks GB, Matthews M, Woolcock AJ. Changes in mite allergen Der $p$ I in house-dust following spraying with tannic acid/acaricide solution. Clin Exp Allergy 1992; 22: 67-74.

157. Marks GB, Tovey ER, Green W, Shearer M, Salome CM, Woolcock AJ. House dust mite allergen avoidance: a randomized controlled trial of surface chemical treatment and encasement of bedding. Clin Exp Allergy 1994; 24: $1078-1083$.

158. Huss RW, Huss K, Squire EN, et al. Mite allergen control with acaricide fails. J Allergy Clin Immunol 1994; 94: $27-32$
159. Warner JA, Marchant JL, Warner JO. Allergen avoidance in the homes of atopic asthmatic children: the effect of Allersearch DMS. Clin Exp Allergy 1993; 23: 279-286.

160. Ehnert B, Lau-Schadendorf S, Weber A, Buettner P, Schou C, Wahn U. Reducing domestic exposure to dust mite allergen reduces bronchial hyperreactivity in sensitive children with asthma. J Allergy Clin Immunol 1992; 90: 135-138.

161. Arlian LG, Bernstein D, Bernstein IL, et al. Prevalence of dust mites in the homes of people with asthma living in eight different geographic areas of the United States. J Allergy Clin Immunol 1992; 90: 292-300.

162. Green WF, Marks GB, Tovey ER, Toelle BG, Woolcock AJ. House-dust mites and mite allergens in public places. J Allergy Clin Immunol 1992; 89: 1196-1197.

163. Zock JP, Brunekreef B. House-dust mite allergen levels in dust from schools with smooth and carpeted classroom floors. Clin Exp Allergy 1995; 25: 549-553.

164. Boner AL, Peroni DG, Piacentini GL, Venge P. Influence of allergen avoidance at high altitude on serum markers of eosinophil activation in children with asthma. Clin Exp Allergy 1993; 23: 1021-1026.

165. Boner AL, Peroni D, Sette L, Valletta EA, Piacentini G. Effects of allergen exposure-avoidance on inflammation in asthmatic children. Allergy 1993; 48: 119-124.

166. Piacentini GL, Martinati L, Fornari A, et al. Antigen avoidance in a mountain environment: influence on basophil releasability in children with allergic asthma. $J$ Allergy Clin Immunol 1993; 92: 644-650.

167. Peroni DG, Boner AL, Vallone G, Antolini I, Warner JO. Effective allergen avoidance at high altitude reduces allergen-induced bronchial hyperresponsiveness. Am J Respir Crit Care Med 1994; 149: 1442-1446.

168. Boner AL, Comis A, Schiassi M, Venge P, Piacentini GL. Bronchial reactivity in asthmatic children at high and low altitude: effect of budesonide. Am J Respir Crit Care Med 1995; 151: 1194-1200.

169. Arshad SH, Hide DW. Effect of environmental factors on the development of allergic disorders in infancy. $J$ Allergy Clin Immunol 1992; 90: 235-241.

170. Arshad SH, Matthews S, Gant C, Hide DW. Effect of allergen avoidance on development of allergic disorders in infancy. Lancet 1992; 339: 1493-1497.

171. Hide DW, Matthews S, Matthews L, et al. Effect of allergen avoidance in infancy on allergic manifestations at age two years. J Allergy Clin Immunol 1994; 93: 842846.

172. Luczynska CM, Li Y, Chapman MD, Platts-Mills TAE. Airborne concentrations and particle size distribution of allergen derived from domestic cats: measurements using a cascade impactor, liquid impinger and a two-site monoclonal antibody assay for Fel $d$ I. Am Rev Respir Dis 1990; 141: 361-367.

173. Wood RA, Chapman MD, Adkinson NF, Eggleston PA. The effect of cat removal on allergen content in household dust samples. J Allergy Clin Immunol 1989; 83: 730-734.

174. Warner JA. Environmental allergen exposure in homes and schools. Clin Exp Allergy 1992; 22: 1044-1045.

175. Custovic A, Taggart SCO, Woodcock A. House-dust mite and cat allergen in different indoor environments. Clin Exp Allergy 1994; 24: 1164-1168.

176. Reisman RE, Mauriello PM, Davis GB, Georgitis JW, DeMasi JM. A double-blind study of the effectiveness of a high-efficiency particulate air (HEPA) filter in the treatment of patients with perennial allergic rhinitis and asthma. J Allergy Clin Immunol 1990; 85: 1050-1057. 
177. Kirsch CM, Payan DG, Wong MY, et al. Effect of eicosapentaenoic acid in asthma. Clin Exp Allergy 1988; 18: 177-187.

178. Arm JP, Horton CE, Mencia-Huerta JM, et al. Effect of dietary supplementation with fish oil lipids on mild asthma. Thorax 1988; 43: 84-92.

179. Picardo C, Castillo JA, Schinca J, et al. Effects of a fish oil enriched diet on aspirin intolerant asthmatic patients: a pilot study. Thorax 1988; 43: 93-97.

180. Thien FCK, Mencia-Huerta JM, Lee TH. Dietary fish oil effects on seasonal hay fever and asthma in pollensensitive. Am Rev Respir Dis 1993; 147: 1138-1143.

181. Dry J, Vincent D. Effects of fish oil diet on asthma: results of a 10 year double-blind study. Arch Appl Immunol 1991; 95: 156-157.

182. Javaid A, Cushley M, Bone MF. Effect of dietary salt on bronchial reactivity to histamine in asthma. BMJ 1988; 297: 454.

183. Lieberman D, Heimer D. Effect of dietary sodium on the severity of bronchial asthma. Thorax 1992; 47: 360-362.

184. Carey OJ, Locke C, Cookson JB. Effect of alterations of dietary sodium on the severity of asthma in men. Thorax 1993; 48: 714-718.

185. Burney PGJ, Neild JE, Twort CHC, et al. Effect of changing dietary sodium on the airway response to histamine. Thorax 1989; 44: 36-41. 